\title{
THE EFFECTIVE PUBLICATION OF GRASSLAND RESEARCH
}

B. T. ROBERTSON

Tussock Grasslands and Mountain Lands Institute, Lincoln College

\begin{abstract}
The effectiveness of the communication of research results from scientists to farmers has been the subject of much previous comment, both in New Zealand and overseas. Some of this is reviewed. Improvements in existing procedures are seen as desirable and necessary. Some changes, especially relevant to the New Zealand pastoral scene, are suggested. Scientists must be assisted to communicate the results of their research, in easily understood language. It should be mandatory for scientists to accompany their relevant scientific papers with a copy for lay consumption. Where necessary, skilled media assistance should be sought. It is argued that primary responsibility for initiating these necessary changes lies with those directing or leading research divisions, regional research stations, universities and with the New Zealand Grassland Association.
\end{abstract}

\section{INTRODUCTION}

An effective form of publicity is central to the successful transmission of grassland technology from scientists to farmers. The publication of scientific information in its broadest sense can take many forms, namely:

(a) By scientists themselves through scientific papers, conference addresses or talks at field days.

(b) By advisers and extension workers using the well-known techniques of field days, discussion groups, farm visits, advisory booklets, journal and newspaper articles, radio talks and so on.

(c) By farmers themselves discussing experience with other farmers or by observing neighbours.

Although there are many pathways of communication. I see the direct transmission of the grassland message from scientist to farmer as shown below: 


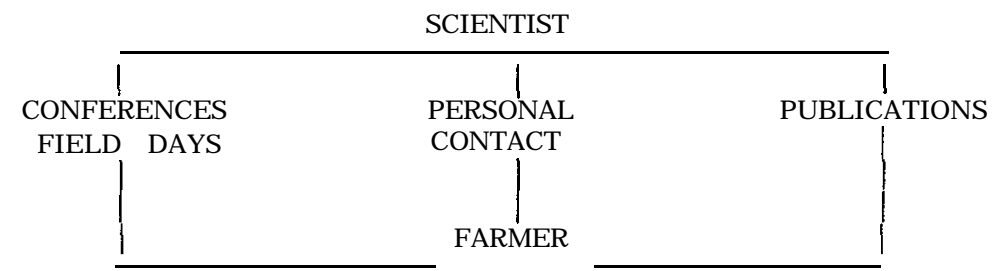

Clearly scientists participate actively in the pubication of research results, although as Baumgart (1970) has observed "few are really good at extension". Conversely, I believe some scientists are more effective communicators than some farm management advisers.

\section{THE SCIENTIFIC PAPER}

An important function of the scientist is to conduct research: that of the scientific paper to inform and add to the bank of knowledge validated information useful to others. In the main the results of scientific endeavour are confined to scientific journals only rarely do they find their way into farming journals and newspapers. There are, of course, exceptions to this, such as the regular press contributions made by Invermay scientists and their liaison officer.

Elworthy (1973) has commented that some modification of the -current form of scientific communication is required, whilst Cumberland (1978) went further and propounded the view that scientific papers were a centuries-outdated institution. Overseas, Leaver (1978) has commented that scientific papers are a poor medium of communcation of research findings of the industry. Scientific papers, as a means of communication between scientists have an important role, but as a means of communication to farmers they are, as Cumberland (loc. cit.) put it, lamentable. Research papers, as such, are intended for a limited audience. Conference papers, aimed at a wider audience, are seldom modified to meet the needs of that audience. They sin against the first two commandments of good journalism:

Thou shalt be concise.

Thou shalt keep it. simple.

By their very nature scientific papers tend to be abtruse, couched in scientific language, and are usually quite lengthy. In 
my experience few farmers read scientific journals, yet this remains the principal source of written information.*

As an agricultural editor I attended several agricultural conferences and took away with me copies of papers delivered. More often than not, these were identical with those eventually published. Very seldom did I receive copy which required little editing or was acceptable for general readership in the form presented.

Most newspaper people are too busy to turn scientific papers into good readable copy. Others may not be qualified to do so. In the interests of accuracy and objectivity, it is preferable for this function to be performed by qualified people skilled in journalism rather than by someone who may distort the message.

In the extension process, newspapers and journals perform the very necessary function of making farmers aware of new techniques, new species, management systems, and so on. If these sources do not receive easily understood information from scientists, one of the. main avenues for "awareness" communication has not been utilized.

This is tragic. The scientist's task of communicating relevant scientific information does not stop with the presentation of papers to conferences or with publication in scientific joumals. Something more is needed - the system has to be changed.

\section{MODIFICATIONS}

It is my believe that relevant scientific papers must be complemented by a modified version to meet the needs of both listeners at conferences and those of the interested reading public.

At present before a scientist can publish a paper it has to undergo departmental editorial scrutiny and be forwarded to a referee for comment. This is a necessary and important procedure. But in the interests of effective communication, a paper for popular consumption should accompany the scientific paper - in fact, I believe it should be mandatory for scientists to do this.

I agree with Fyfe (1975) who commented that scientists have a responsibility to report simply to advisory officers and farmers when they have something to say. Regrettably, but understandably,

*Gunning, who devised a yardstick for measuring readability, called writing which makes difficult reading "foggy". His yardstick is called the "Fog Index". A sample of papers, presented to past Grassland Association conferences, has been analysed for "fogginess" and the results appear as an appendix to this paper. 
few are skilled at this, so media help must be employed. Some groups of scientists employ people whose job it is to extend the scientific message - many scientists are, however, left "out in the cold". I strongly recommend that media extension people be available to assist all scientists in this task.

Similarly, papers suitable for publication are seldom suitable for conference delivery. It is incumbent on scientists to produce another version to meet the needs of a listening audience. The responsibility for initiating these changes lies with those directing or leading research agencies and divisions, regional research stations, and faculties of agriculture.

\section{MAKING USE OF THE MEDIA}

As a newspaper journalist, I found it was necessary to take the initiatives and approach scientists for suitable newsworthy information. Not once was I approached by a scientist. I believe this experience is not unique. By adopting such a stand-offish attitude, scientists merely reflect the wishes of their supervisors who insist on scrutinizing copy before it goes to press. I find this policy hard to understand, if not a little inconsistent. Reporters attend field days or conferences and they try to interpret what they hear, for publication. Their copy is not scrutinized for error. What is so different about visiting a research institution, or interviewing scientists about their work?

It would seem there is room for research directors and others tc trust their scientists a little more and allow them freer access to the media. If the policy in his sphere of communication were reconsidered I am hopeful scientists would approach the media with newsworthy information.

\section{POPULAR JOURNALS}

At present, the main reference point for research is the scientific paper. Is this one source enough? I believe not. Little use is made of popular farming journals for regularly reporting research results: The New Zealand Farmer does run a regular feature "Research in Brief" which reports, in precis form, current information. In 1979, however, of 177 items published on this page only 61 were of New Zealand origin.

The three main farming journals in New Zealand could be used to greater effect by the provision of easily understood relevant research information which could then become a reference point for farmers. The advent of Aglink goes part of the way to meeting the 
need for another reference point but not every farmer receives Aglink. Most do receive one of the three main journals. I make this point because farmers have not the time, nor perhaps the inclination, to read lengthy scientific or conference papers - if, indeed, they are aware of their existence.

Without effective communication of what use is research?

\section{GRASSLAND CLUBS}

There is yet another avenue for the effective communication of grassland research - an avenue which could well be exploited by the New Zealand Grassland Association, containing as it does a wide farmer membership. I suggest that small regional Grassland Clubs be set up throughout New Zealand, by the New Zealand Grassland Association, with the aim of giving farmers the opportunity to discuss grassland management with advisory officers and scientists. Such a structure already exists in dairying districts, as Dairy Board-inspired discussion groups. No one would question the great effectiveness of these.

The benefits accruing would be enormous. From the scientists' point of view, it would bring them into close contact with farmers, and vice-versa. Only good could result from such an interchange.

After spending 14 years in extension work, I am convinced that the most effective source of creditable information for farmers is another farmer.

Fairgray (1979) has shown in his survey, on the adoption of rotational grazing practices involving 112 sheep and beef farms in the King Country, that the average farmer felt that contact with neighbouring farmers, observation over the fence, and reading journal articles, were the most important sources of information. The opinions of FAOs in the survey were, however, considerably different. They overestimated their own importance, and that of field days and advisory booklets. Fairgray concluded that "although the methods used by FAOs are effective, by inducing adoption, they should give greater acknowledgement to the importance of inter-farmer contact as a resource to be utilized, rather than merely accepted".

In an earlier study, Fairgray (1977) found that personal sources were clearly dominant as inducers of adoption for farmers changing to Drysdale or Perendale breeds of sheep. Journals and newspapers, however, ranked highly in making farmers aware of these breeds for the first time.

Scientists and advisers should heed these findings. 
On the basis of Fairgray's findings, it would appear there is scope for farm advisers to have a re-think about their methods of communication. A case exists to make extension studies a compulsory subject for farm management degree students, many of whom enter the advisory profession. It seems ludicrous to me that, whilst core subjects are a compulsory component of a degree course, the attainment of knowledge of extension skills is not.

In 1973, Harbord observed that "possibly the greatest barrier to improved scientific publication in New Zealand is the illusion among scientists that effective communication is already being achieved". I am hopeful that the new initiatives I have suggested, if adopted, will dispel such an illusion if it indeed exists.

\section{CONCLUSION}

I have made a plea for improvements in the direct communication of the grassland message from scientists to farmers. I place responsibility for initiating changes for the more effective publication of grassland research with those directing or leading research agencies and divisions, regional research stations, and agricultural faculties at universities. New initiatives and action frequently occur only when orders come from above - so it is there that the responsibility for action lies and where the winds of change begin to blow. Who, among our scientific generals, has the vision to see the problem and has the courage to take the initiatives necessary to overcome them?

The New Zealand Grassland Association has a marvellous opportunity to extend the grassland message on a regional basis through the co-operation of MAF, DSIR, the New Zealand Society of Farm Management, and the New Zealand Institute of Agricultural Science. These bodies joining forces can create the machinery necessary for the effective communication of the grassland message to farmers in their own regions.

\section{SUMMARY}

Scientists must be assisted to communicate the results of their research in easily understood language, It should be mandatory for scientists to accompany their relevant scientific papers with a copy for lay consumption. Where necessary skilled media assistance should be sought.

Popular farming journals are at present under-utilized in the extension of research information. 
I believe the grassland message would be most effectively publicized by the formation of small regional grassland clubs consisting of farmers, advisers and scientists.

\section{ACKNOWLEDGEMENTS}

The author gratefully acknowledges the assistance of the Teaching Aids Section, Lincoln College, and Miss S. P. Townsend of the Tussock Grasslands and Mountain Lands Institute, Lincoln College.

\section{REFERENCES}

Baumgart, 1. L., 1970. Proc. A gric. Extension Seminar, M assey University. Cumberland, G. L. 'B., 1978. N.Z, agric. Sci., 12 (4): 129-31.

Elworthy, P. H., 1973. N.Z. agric. Sci., 7 (3): 107-9.

Fairgray, J. D. M., 1977. A uckland Student Geographer: 23-33.

1979. Proc. 10th N.Z. Geogr. Conf. and 49th A NZAAS Congr., Geogr. Sci.: 188-91.

Fyfe, D. L., 1975. Proc. N.Z. Grassld A ss., 36 (2): 137-40.

Gunning, R., 1968. The Technique of Clear Writing. McGraw-Hill, New York.

Harbord, M. W., 1973. N.Z. agric. Sci., 7 (3): 105-7.

Leaver, J. D., 1978. Agric. Progress, 53: 10-33.

\section{APPENDIX}

Fog Index* of a random sample of papers published in the Proceedings of the New Zealand Grassland Association, 1972 to 1978.

\begin{tabular}{lccc}
\hline & \multicolumn{3}{c}{ Authors } \\
\cline { 2 - 4 } & Farmers & $\begin{array}{c}\text { Farm } \\
\text { Advisory } \\
\text { Officers }\end{array}$ & Scientisis \\
\hline $\begin{array}{l}\text { Average Fog Index } \\
\text { Range }\end{array}$ & $8.5-11.0$ & 13.0 & 15.0 \\
\hline
\end{tabular}

*This index measures readability and is based on a scale of 6 to 17 (approximate New Zealand reading standard: $6 \cong$ Form $1,12 \cong$ Form 7 ). 